\title{
COMPARISON OF NON-LINEAR MASONRY INFILL MACRO-MODELS
}

\author{
Tanja Kalman Šipoš \\ Josip Juraj Strossmayer University of Osijek, Faculty of Civil Engineering Osijek, PhD. \\ Vladimir Sigmund \\ Josip Juraj Strossmayer University of Osijek, Faculty of Civil Engineering Osijek, Full Professor
}

\begin{abstract}
Reinforced-concrete frames with masonry infill are composite systems, common in low and medium-high buildings, whose behavior under earthquake loads is difficult to predict. Because of that, most national codes ignore the contribution of infill to the structural response. In this paper, we determined the seismic behavior of infilled frames by using a numerical non-liner model (with various geometries and various masonry and $\mathrm{r} / \mathrm{c}$ frame properties), using samples taken from the originally collected experimental data base on infilled frames "EDIF". We then compared these experimental results to numerical models designed using recommendations from FEMA 356 (nonlinear model), Eurocode 8 (linear model), and other published methods (Stafford-Smith and Carter, Mainstone, Žarnić, Paulay and Priestley) in order to assess the most suitable, rational macro model for evaluating the behaviour of masonry infill in a reinforcedconcrete frame during earthquake excitation.
\end{abstract}

Key words: infilled frames, masonry infill, macro-model, non-linear analysis

\section{USPOREDBA NELINEARNIH MAKROMODELA ZIDANIH ISPUNA}

Sažetak: Armiranobetonski okviri sa zidanom ispunom predstavljaju kompozitne konstrukcije, dominante u području niskih i srednje visokih građevina, čije je ponašanje pri djelovanju potresa teško predvidjeti. Zbog toga se doprinos zidane ispune odgovoru konstrukcije općenito zanemaruje u većini nacionalnih propisa. Ponašanje uokvirenog ziđa pri djelovanju potresa primjenom numeričkog nelinearnog modela dokazano je uporabom eksperimentalnih uzoraka iz EDIF eksperimentalne baze i usporedbom prema metodama projektiranja uokvirenog ziđa u FEMA 356 (nelinearni model), Eurokodu 8 (linearni model), te drugim metodama (StaffordSmith i Carter, Mainstone, Žarnić, Paulay and Priestley). Ova usporedna studija provedena je radi dobivanja najprikladnijeg i najracionalnijeg modela zidane ispune u armiranobetonskim okvirima pri djelovanju potresa.

Ključne riječi: uokvireno ziđe, zidana ispuna, makromodel, nelinearni proračun 


\section{Introduction}

Reinforced-concrete frames infilled with masonry are composite structural systems ("framed-masonry") that are effective against in-plane horizontal loads produced by wind and earthquake because of their greater stiffness and strength than bare frames. As system, its structural behavior depends on the individual characteristics of its components: the reinforced concrete frame and masonry infill and their particular interaction [1].

The composite behavior of the components significantly enhances stiffness and strength of the system, especially at small drifts. The infill acts as a rigid element that reduces the deformation of the frame structure when subjected to earthquake action. However, it also increases the weight and stiffness of the system that "attracts" larger seismic forces due to the reduction of the vibration period. Because of this effect, when analyzing new and existing building it is very important to incorporate infill-frame interactions and consider the masonry infilled frames as one system [2, 3]. Most national codes do not recognize the "framed-masonry" as a system as there is no consensus about the behavior and influence of the infill walls on the system's response. That is partly due to incomplete understanding of its knowledge of the behavior of unreinforced masonry and the composite behavior of the frame and the infill, as well as due to the lack of conclusive experimental and analytical results, despite extensive experimental efforts [4].

In this the composite "framed-masonry" structure is simulated by the fiber macro-element frame model and panel macro-model with equivalent struts for the masonry infill wall [5]. The number of influential parameters that affect the calculated response is rather large. Despite the many experimental results now available, it is rare to find in the literature a comparison of results from two or more distinct sources in order to draw definitive conclusions about their influence. One of the most important parameters is the equivalent strut width and its corresponding properties in order to achieve a realistic building response [6].

\section{Modeling of masonry infill}

\subsection{General}

To evaluate how lateral load affects infilled frames, researchers have developed various methods that idealize the system's behavior with the aim to define simple, physically acceptable macro-models that are realistic surrogates for designing new structures and evaluating existing ones. Framed-masonry structures are a composite of reinforced-concrete frames and masonry infill. Macro-models for reinforced-concrete frames exist for a long time and have been verified on many experiments and mere addition of the macro-model for masonry infill seemed a logical option. Macro-models for the masonry infill include simplified models based on a physical understanding of the behavior of masonry infill within the frame.

This concept assumes that, regardless of failure mode, the masonry infill will separate in opposite corners, allowing the entire masonry infill to be replaced with a compression diagonal strut (Fig. 1). The model of equivalent strut is widely accepted as a simple and rational method of presenting the influence of masonry infill in the frame structure. The concept of equivalent strut was first presented by Polyakov [7], then by Holmes [8] and Stafford-Smith [9]. Several researchers have developed different approaches for methods of determining the equivalent strut width and horizontal stiffness [7-9].The characteristics that define the equivalent strut model differ by the type of analysis (linear or nonlinear elastic) and type of load (static or dynamic) as they influence the system's behaviour. For linear elastic analysis it is sufficient to know the area, length of the strut, and the elastic modulus of masonry in order to calculate the elastic stiffness of masonry infill.

However, when the structure is dynamically loaded, a single diagonal cannot properly transmit compressive and tensile forces in the frame elements. Representing the effect of the masonry infill requires at least two diagonals. When compressive forces develop in these diagonals, they are considered active. Rather than using only the elastic modulus of the masonry, a more accurate approach is required that takes into account the nonlinear material properties given by the stress-strain relationship of the masonry under biaxial-stress state and the hysteretic behavior of materials must be accounted for. 
a)



c)

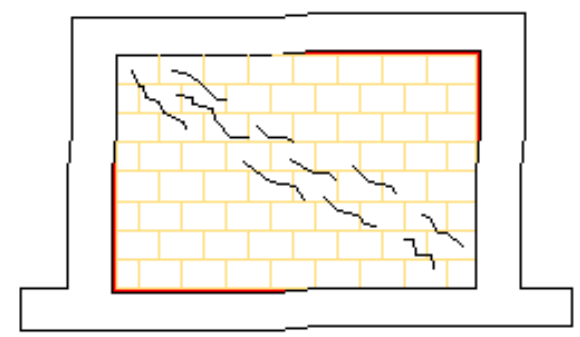

b)



d)

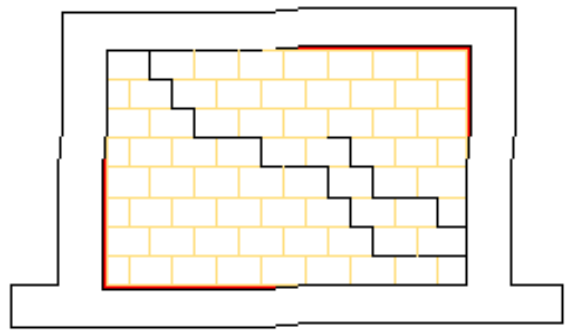

Figure 1.Equivalent strut,showing the modes of failure for the infill:

a) Horizontal sliding shear, b) corner crushing, c) diagonal cracking, d) bed-joint sliding shear

\subsection{Defining the equivalent diagonal width}

One of the most important parameters in modelling the masonry infill with the strut model is the strut width $w$. Researchers have provided many recommendations for the diagonal strut width depending on the dimensionless parameter of stiffness $\lambda_{\mathrm{h}}$ or on the length of the diagonal $d$. However, using these recommendations leads to a wide range of diagonal widths, and as such must be verified with regard to the relevant results obtained by experiments. We analyzed the following recommendations for determining the strut width $w$ : Stafford-Smith and Carter, Mainstone, Žarnić, Fema 356, Eurocode 8, and Paulay and Priestley [10-15].

Studying the behavior of square frames with infill, Stafford-Smith (1965) suggested that the strut width is not constant and should be expressed as a function of the relative stiffness between the frame and infill, with the contact length on the loaded corners [9]. Stafford-Smith and Carter developed a method to analyze infilled frames based on the concept of the equivalent strut [10]. In their method, the horizontal stiffness of an infilled frame depends on the effective width of the equivalent diagonal, which changes with deformation induced by stress in the masonry. The horizontal strength of the infilled frame is based on the weakest of several failure modes. To conclude that the width of the strut is not constant, they developed a series of design charts for their determination (Fig. 2). The parameter $\lambda_{h}$ is a measure of the relative stiffness between the frame and masonry infill; greater $\lambda_{h}$ corresponds to a more flexible frame. It can be determined using the following equation:

$$
\lambda_{h}=h \sqrt[4]{\frac{E_{i} \cdot t \cdot \sin (2 \theta)}{4 E_{c} \cdot 1 \cdot h_{w}}}
$$

where $h$ is the height of frame between the beam axis, $h^{\prime}$ is the height of the masonry infill, $E_{c}$ is the modulus of elasticity of the column, $E_{i}$ is the modulus of elasticity of the masonry infill, $I$ is the moment of inertia of the column, and $\theta$ is the slope angle of the infill diagonal. The diagonal stiffness and strength of the infill depend on the contact length between the infill and frame $\alpha$, which is expressed as follows:

$$
\alpha=\frac{\pi}{2 \lambda}
$$

Stafford-Smith and Carter [10] have developed design charts for defining the w/d ratio, where $w$ is the strut width and $d$ is the length of the infill diagonal. This ratio is expressed by $\lambda_{h}$ and the ratio of the panel length to 
height $L / h$. For each $L / h$ ratio, the functions are presented for two load conditions: $R / R_{c}=0$ and 1 , where $R$ and $R_{c}$ are the loads corresponding to the imposed force (initial diagonal width) and the force that represents the collapse of the infill (final diagonal width). To simplify their application, the curves are approximated by seconddegree polynomial functions (Fig. 2).

$\mathrm{L} / \mathrm{h}=2: 1$

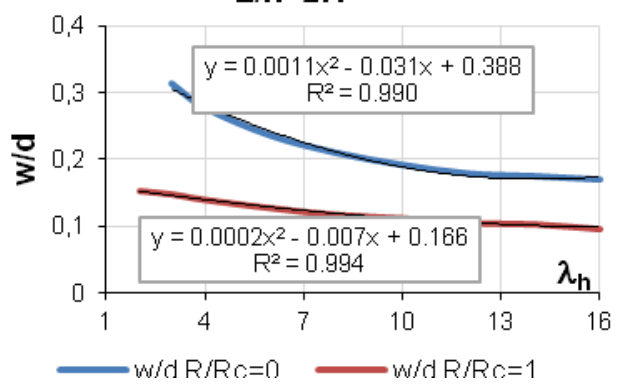

$\mathrm{L} / \mathrm{h}=1: 1$

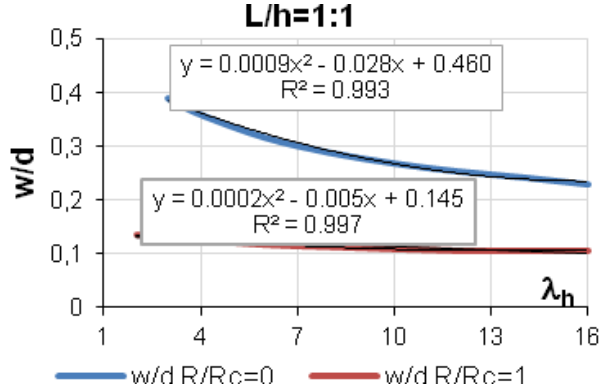

$\mathrm{L} / \mathrm{h}=2,5: 1$

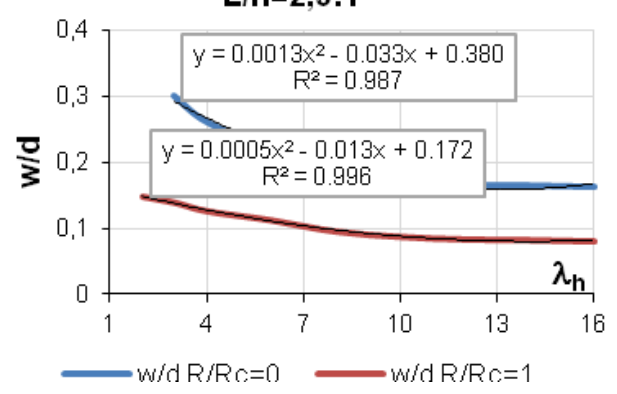

$\mathrm{L} / \mathrm{h}=1,5: 1$

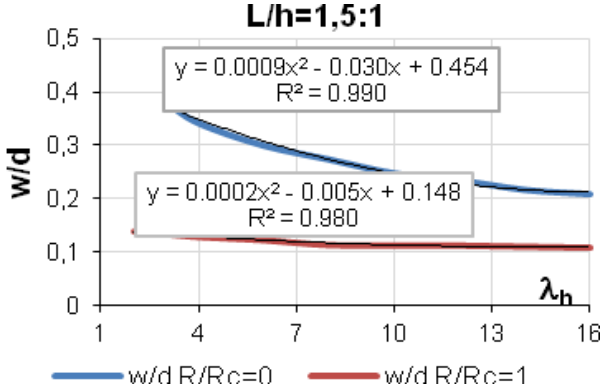

Figure 2. Approximate wd functions [10]

Mainstone [11], studying the behavior of plane infilled frames, developed empirical formulas for the equivalent width of the diagonal, using the parameters $W_{e k}^{\prime}, W_{e t}^{\prime}$ and $w_{e c}^{\prime}$. These are the initial stiffness, force at the first crack, and the limit capacity of the infill, respectively, which depend on the parameter $\lambda_{\mathrm{h}}$, the relative stiffness of the frame and infill given by Stafford-Smith and Carter (Table 1). The most commonly used formula developed by Mainstone is shown in Eq. (3). This formula, included in the modeling proposition of infilled frames in FEMA 356 [13], is taken from Table 1 for modeling the masonry infill at the initial stiffness.

$$
w=0,175\left(\lambda_{h}\right)^{-0,4} \cdot w^{\prime}
$$

$w^{\prime}$ - characteristic width of the diagonal, equal to $d^{\prime} \sin 2 \theta$, where the $d^{\prime}$ is the length of infill diagonal

Table 1. Empirical equations for the width of the masonry infill diagonal [11]

\begin{tabular}{|c|c|c|}
\hline & masonry unit & concrete unit \\
\hline For $\lambda_{h}{ }^{1}<5$ & $\begin{array}{l}\mathrm{w}_{\mathrm{eK}}^{\prime}=0,175\left(\lambda_{h}\right)^{-0,4} \cdot \mathrm{w}^{\prime} \\
\mathrm{w}^{\prime}{ }_{\mathrm{et}}=0,170\left(\lambda_{\mathrm{h}}\right)^{-0,4} \cdot \mathrm{w}^{\prime} \\
\mathrm{w}_{\mathrm{ec}}=0,56\left(\lambda_{\mathrm{h}}\right)^{-0,875} \cdot \mathrm{w}^{\prime}\end{array}$ & $\begin{array}{l}\quad w_{\text {eK }}^{\prime}=0,115\left(\lambda_{h}\right)^{-0,4} \cdot w^{\prime} \\
w_{\text {et }}^{\prime}=0,225\left(\lambda_{h}\right)^{-0,4} \cdot w^{\prime} \\
w_{\text {ec }}^{\prime}=0,840\left(\lambda_{h}\right)^{-0,875} \cdot w^{\prime}\end{array}$ \\
\hline For $\lambda_{h}>5$ & $\begin{array}{l}w_{\text {eK }}^{\prime}=0,160\left(\lambda_{h}\right)^{-0,3} \cdot w^{\prime} \\
w^{\prime}{ }_{e t}=0,150\left(\lambda_{h}\right)^{-0,3} \cdot w^{\prime} \\
w^{\prime}{ }_{e c}=0,520\left(\lambda_{h}\right)^{-0,8} \cdot w^{\prime}\end{array}$ & $\begin{array}{l}w_{\text {eK }}^{\prime}=0,180\left(\lambda_{h}\right)^{-0,3} \cdot w^{\prime} \\
w^{\prime}{ }_{e t}=0,220\left(\lambda_{h}\right)^{-0,3} \cdot w^{\prime} \\
w^{\prime}{ }_{e c}=0,780\left(\lambda_{h}\right)^{-0,8} \cdot w^{\prime}\end{array}$ \\
\hline
\end{tabular}

1 - Stiffness parameter according to Eq. (1) 
Žarnić suggested an analytical method to calculate the area of the diagonal strut,assuming that the axial stiffness of the diagonal is equal to the stiffness of the triangular part of the infill, which remains after infill collapse [12]:

$$
A_{s}=K_{t} \frac{I_{p}}{E_{p}} ; \quad h_{s}=\frac{A_{s}}{t_{p}} ; \quad K_{t}=\frac{1}{\frac{5 \cdot h_{t}^{3}}{12 \cdot E_{p} \cdot I_{p}}+\frac{0,6 \cdot h_{t}}{G_{p} \cdot A_{p}}} ; \quad h_{t}=\frac{2}{3} h_{p}
$$

where $K_{t}$ is the stiffness of the masonry infill, $h_{s}$ is the width of the diagonal strut, $h_{p}$ is the height of the infill, $I_{p}$ is the length of the infill, $t_{p}$ is the thickness of the infill, $E_{p}$ is the modulus of elasticity, $G_{p}$ is the shear modulus $\left(G_{p} \approx 10-30 \%\right.$ of $\left.E_{p}\right), A_{p}$ is the area of the horizontal cross-section of the infill, and $I_{p}$ is the moment of inertia of the horizontal cross-section of the infill.

Paulay and Priestley noted that a wider strut leads to a stiffer structure, causing a higher seismic response. They proposed a diagonal strut width of 0.25 times its diagonal length [15].

FEMA 356 [13] recommends a strut area equal to the product of the thickness and width of the masonry infill diagonal, based on the recommendations of Mainstone [11], limiting their use to infills made of masonry units and $\lambda_{h}<5$. Thematerial properties of the diagonal struts are the same as those of the masonry infill.

Eurocode 8 [14] (chapter 5 of EN 1998-1) noted that the masonry infill can be modeled using a strut along the compressive diagonal of the infill, based on the analogy of a beam on elastic soil presented by Mainstone [11]. Alternatively, they allow for a fixed strut width having $15 \%$ of diagonal length of the infill. For linear analysis, the equivalent diagonal must be defined as an elastic element with a cross-sectional area equal to the product of the width and thickness of the masonry infill with the same modulus of elasticity as the masonry infill.

\subsection{Infill panel element}

The infill panel element [16] represents the biaxial behavior of the masonry infill in compression and shear by using two parallel diagonal and shear springs for each load direction. This concept was adopted as a numerical model for the masonry infill in the Ruaumoko [17] and Seismostruct [18] structural analysis programs. This configuration of the equivalent strut adequately accounts for the stiffness and capacity of the masonry infill placed within the reinforced concrete frame. To simulate the axial response of the masonry infill during cycling, the model uses the hysteresis rule proposed by Crisafulli [16] (Fig. 3). This model accounts for the nonlinear response of the masonry in compression, including the effects of contact length in cracked material.
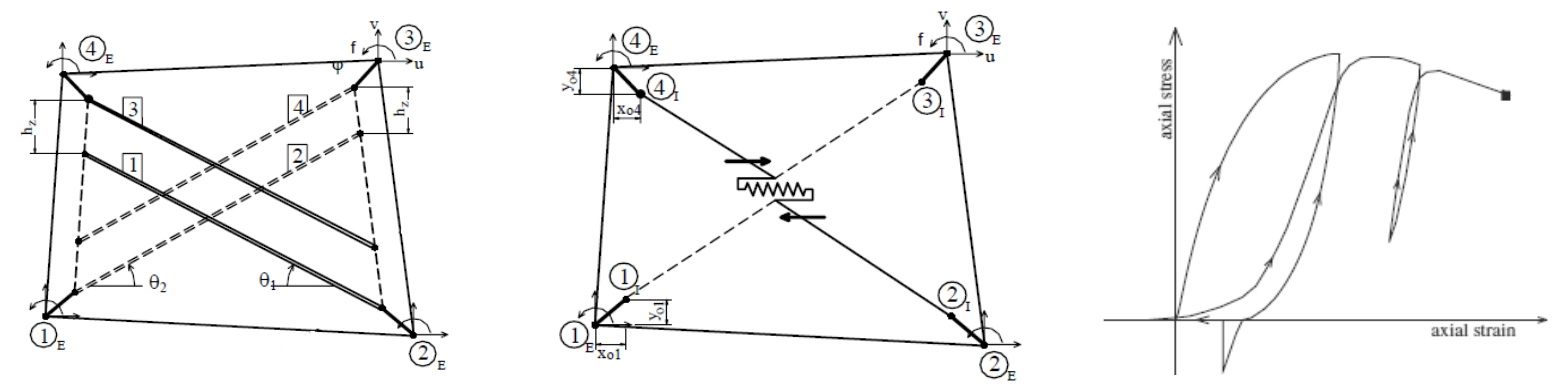

Figure 3. Formulation of panel model:

a) compressive diagonal struts, b) shear springs, c) compressive axial behavior of masonry [16] 

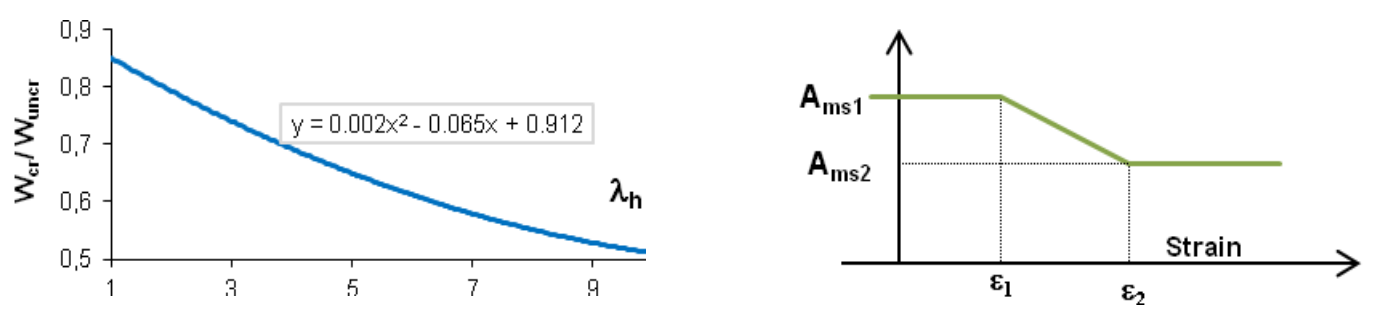

Figure 4. a) Ratio of strut width between cracked and uncracked masonry infills[19] b) Strut area as a function of axial strain [16]

The main advantage of the panel model is that the strut width varies with axial strain. The initial area is calculated according to the recommendations of various authors [10-15], while the final area $A_{m s 2}$ is decreased from the initial area using the recommendation of Decanini and Fantin [19] (Fig. 4).

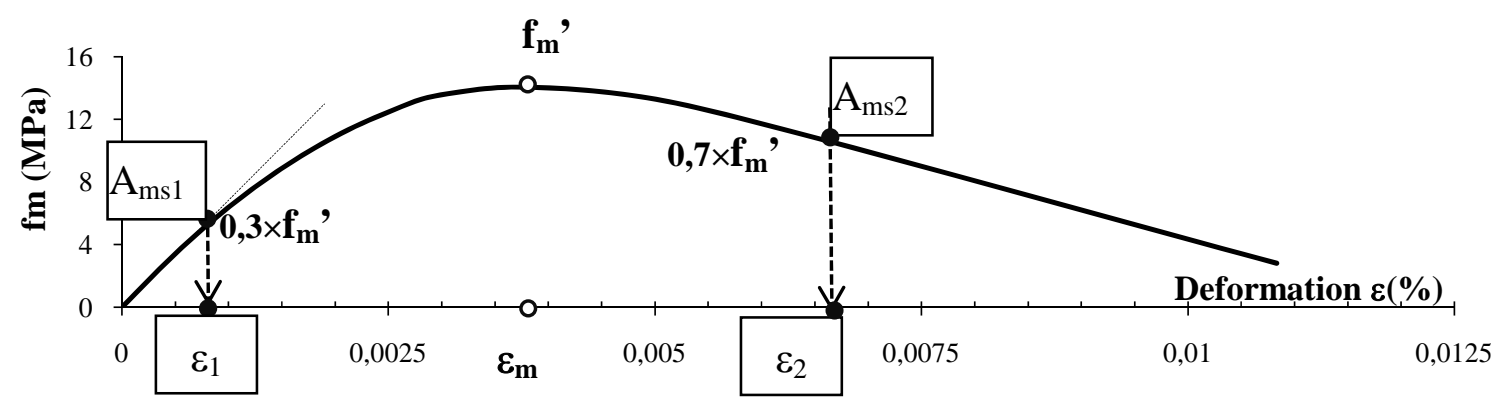

Figure 5. Defining the variability of areas and related deformations

We determined the deformations that correspond to the initial and final strut areas by calibrating experimental samples to the observed limit states: the initial strut area $A_{m s 1}$ corresponds to the deformation at the end of linear elastic behavior $\left(\varepsilon_{m} / 3\right)$, while the secondary area of the strut $A_{m s 2}$ corresponds to $70 \%$ of the maximum compressive stress with the strain corresponding to $1.5 \varepsilon_{m}$ (Fig. 5).

\section{Evaluating the masonry infill macro model}

Evaluation of the macro models of masonry infill was carried out for the panel model as defined in Seismostruct [18]. Macro model of infill suggested by Crisafulli [16] contains the parameters of the hysteresis rule that were calibrated with respect to the results of the experimental samples of three one-bay, one-story infilled frames.

The RC frame elements are modeled as fiber force-based elements with plastic hinges at the ends. They were previously calibrated according to the experimental sample of the RC bare frame given by Žarnić [20]For the material properties of the RC frame, we used the nonlinear confined concrete model by Mander [21] and the nonlinear model for reinforcing steel by Menegotto-Pinto [22].Because the diagonal compressive strength of the masonry infill must include all possible mechanisms of infill's collapse, the relevant compressive strength was the minimum value, the most probable collapse mechanism, evaluated by Bertoldi et al. [23].

\subsection{Experimental samples and input data for modeling one-story, one-bay infilled frames}

In order to evaluate the macro model, three experimental samples of one-story, one-bay infilled frames were selected from EDIF experimental database [24] compiled previously. These samples include masonry infills with low, moderate, and high compressive strength and have different ratios of frame height to length. From the 
experiments conducted by Colangelo [25], two samples were selected: one infilled frame with low compressive strength (N2), and one with medium compressive strength (C1). The sample with the strong infill (M2) was experimentally examined by Žarnić [20]. All three samples were experimentally tested at a 1:2 scale, applying cyclic horizontal load at the beam axis and a constant vertical axial force on each column (190 kN on each column for sample N2, $250 \mathrm{kN}$ for sample C1, and $100 \mathrm{kN}$ for sample M2). We present the experimental results of the infilled frames using primary force-displacement curves, characterized by the yield and ultimate capacity of the infilled frames.

Table 2. Material and geometric properties of experimental samples

\begin{tabular}{|c|c|c|c|c|}
\hline & Colangelo N2 & Colangelo C1 & Žarnić M2 \\
\hline \multirow{8}{*}{ 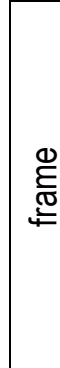 } & $H / L$ & 0.57 & 0.75 & 0.70 \\
\hline & column b/h (m) & $0.2 / 0.2$ & $0.2 / 0.2$ & $0.22 / 0.22$ \\
\hline & ratio $\rho_{c}$ & 0.024 & 0.017 & 0.033 \\
\hline & beam $b / h(m)$ & $0.2 / 0.25$ & $0.2 / 0.25$ & $0.22 / 0.22$ \\
\hline & ratio $\rho_{B}$ & 0.0094 & 0.009 & 0.033 \\
\hline & $f_{c}(\mathrm{MPa})$ & 44.5 & 43.7 & 15.2 \\
\hline & $E_{c}(\mathrm{MPa})$ & 35576 & 35390 & 17860 \\
\hline & $f_{y}(\mathrm{MPa})$ & 578 & 531 & 456 \\
\hline \multirow{3}{*}{ 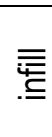 } & $t(\mathrm{~m})$ & 0.16 & 0.12 & 0.12 \\
\hline & $f_{k}(\mathrm{MPa})$ & 2.74 & 5.10 & 14.4 \\
\hline & $E_{i}(\mathrm{MPa})$ & 1212 & 4230 & 5486 \\
\hline
\end{tabular}

Table 3. Parameters used to calculate diagonal width according to different authors

\begin{tabular}{|c|c|c|c|c|c|}
\hline & Parameter & Legend & N2 & C1 & M2 \\
\hline \multirow{5}{*}{$\begin{array}{l}\text { Stafford- } \\
\text { Smith and } \\
\text { Carter }\end{array}$} & $\lambda h$ & stiffness parameter & 2.3 & 3.01 & 4.17 \\
\hline & $w / d\left(R / R_{c}=0\right)$ & Fig. 2 & 0.173 & 0.260 & 0.302 \\
\hline & $w_{1}\left(R / R_{c}=0\right)(\mathrm{m})$ & & 0.46 & 0.56 & 0.77 \\
\hline & $w / d\left(R / R_{c}=1\right)$ & Fig. 2 & 0.102 & 0.115 & 0.122 \\
\hline & $w_{2}\left(R / R_{c}=1\right)(m)$ & & 0.27 & 0.25 & 0.31 \\
\hline \multirow{2}{*}{ Mainstone } & $\overline{~ w^{\prime}}$ & Table 1 & 2.26 & 2.07 & 2.43 \\
\hline & $W_{e K}^{\prime}(\mathrm{m})$ & Table 1 & 0.17 & 0.17 & 0.22 \\
\hline $\begin{array}{l}\text { Paulay and } \\
\text { Priestley }\end{array}$ & $w(\mathrm{~m})$ & $25 \% d$ & 0.66 & 0.53 & 0.64 \\
\hline Fema 356 & $w(\mathrm{~m})$ & Eq. (3) & 0.17 & 0.16 & 0.22 \\
\hline EC8 & $w(\mathrm{~m})$ & $15 \% d$ & 0.40 & 0.32 & 0.38 \\
\hline \multirow{6}{*}{ Žarnić } & $h_{t}=2 / 3 h^{\prime}$ & eccentric diagonal height & 0.87 & 0.87 & 1.00 \\
\hline & $b\left(^{\circ}\right)$ & diagonal strut angle & 19.10 & 24.50 & 23.48 \\
\hline & $I_{s}$ & diagonal length & 2.65 & 2.09 & 2.51 \\
\hline & $K_{t}$ & stiffness of triangular part & 95098.03 & 151153.05 & 217334.11 \\
\hline & $A_{s}$ & strut area & 0.19 & 0.06 & 0.08 \\
\hline & $w=h_{s}$ & strut width & 1.16 & 0.51 & 0.70 \\
\hline
\end{tabular}

Table 3 shows the parameters for non-linear analysis related to the initial diagonal width, except for Stafford-Smith and Carter [10] in which the direct referral to the final area of the equivalent diagonal strut $A_{m s 2}=t \times w_{2}$ is provided. For all other strut-width recommendations, the final strut areas were accepted according to Decanini [19]. 


\subsection{Results of nonlinear analysis of one-story, one-bay infilled frames}

The evaluation of nonlinear masonry infill model was carried out by comparison of the results obtained by nonlinear analysis and results observed in each experimental sample by comparison of yield and ultimate forces and inter-story drift ratio values. Force-displacement curves obtained by the non-linear analysis represent pushover curves.

The yield force $\left(V_{y}\right)$ and corresponding drift ratio $\left(d_{y}\right)$ of the framed-masonry represent the change expressed through the creation and development of cracks which do not necessarily represent infill's collapse (graphically represents the significant change in stiffness). The ultimate force $\left(V_{u}\right)$ with the corresponding drift ratio $\left(d_{u}\right)$ is the maximum lateral capacity of framed-masonry structural element.
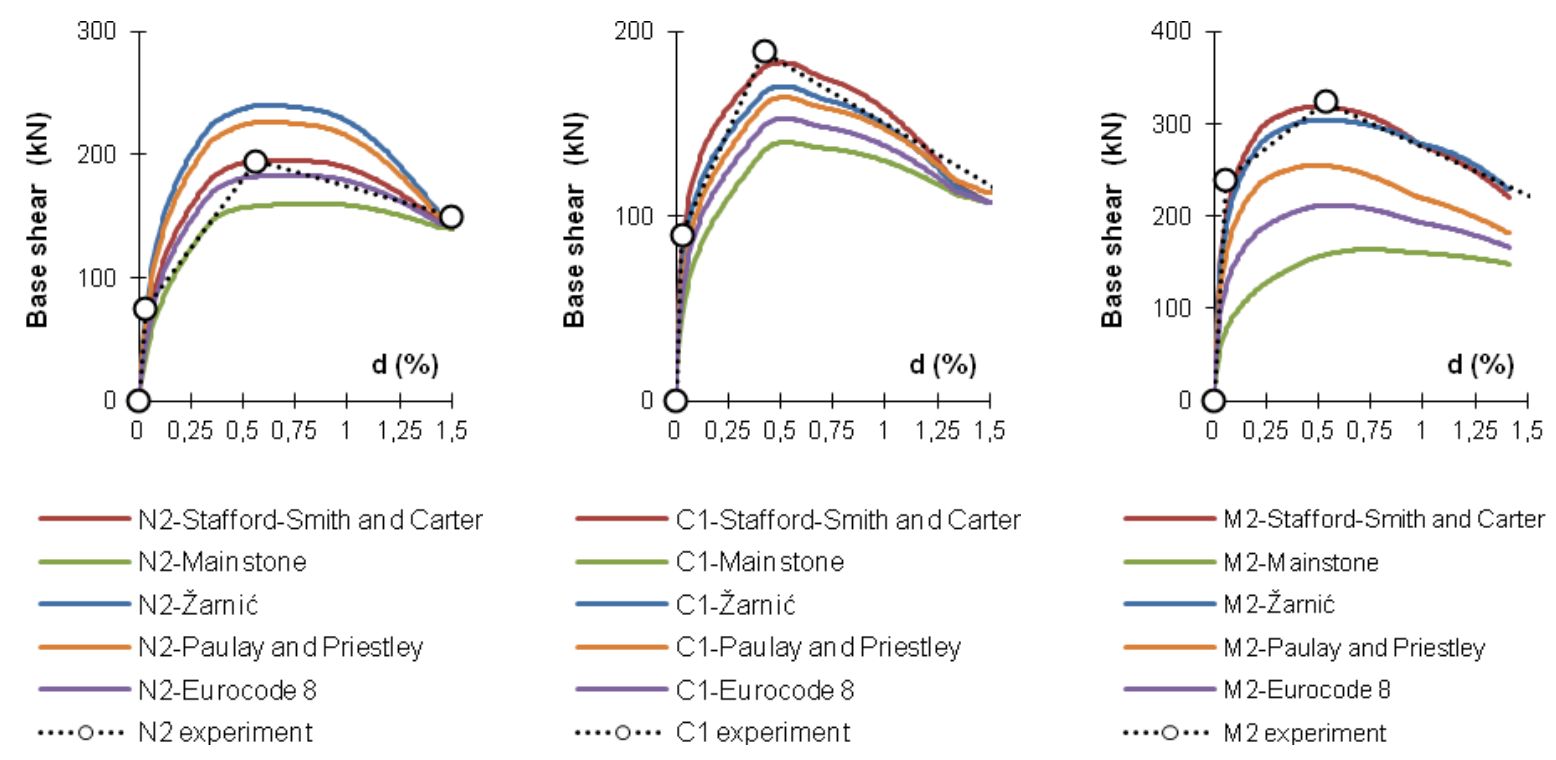

Figure 6. Envelope curves for samples N2, C1, and M2, using different recommendations of strut width

The results from model N2 with a weak masonry infill show that the recommendation by Mainstone [11] for strut width significantly underestimated the experimental stiffness and capacity, while the recommendations by Žarnić [12] and Paulay and Priestley [15] overestimated the yield and ultimate forces. For sample C1 with a medium infill, the numerical results differed from the experimental results in initial stiffness and ultimate capacity, except when using the strut-width recommendations by Stafford-Smith and Carter [10]. For sample M2 given by Žarnić [12], the recommendations for the equivalent strut width by Stafford-Smith and Carter [10] and Žarnić [12] well predicted the experimental initial and secondary stiffness as well as the ultimate capacity.

The recommendations by Stafford-Smith and Carter [10] for the diagonal strut width reliably predicted the experimental behavior of the infilled frames, regardless of the infill type and the ratio of the height to length of the $\mathrm{RC}$ frame. The four observed values of yield drift $d_{y}$, had maximum deviations within reasonable accuracy, with an average relative error of $12 \%$ for all three infilled frames samples. The overall relative average errors for the yield and ultimate values for samples $\mathrm{N} 2, \mathrm{C} 1$, and $\mathrm{M} 2$ were $8 \%, 6 \%$, and $9 \%$, respectively.

Although Mainstone's [11] recommendation for defining the equivalent diagonal width is accepted in FEMA 356 [13], using it led to the highest deviation of strength and stiffness for all three experimental samples. Comparing the experimental and numerical results of the simulated bilinear curves, we conclude that the deviations in terms of relative average errors are significant, regardless of the type of masonry infill. Thus, Mainstone's recommendation is unacceptable.

The recommendations by Žarnić [12] for determining the geometrical characteristics of the diagonal strut gave good results for samples with medium and strong infills. This result was expected because his recommendations were based on his experimental work on infilled frames with medium and strong infills. 
The simplest recommendation by Eurocode 8 [14] and Paulay and Priestley [15], with the diagonal width taken as $15 \%$ and $25 \%$ of the diagonal length, respectively, gave very good results only for RC frames with weak masonry infills.

Table 4. Evaluating the recommendations for equivalent strut width for samples N2, C1, and M2

\begin{tabular}{|c|c|c|c|c|c|c|c|}
\hline & & Experiment & $\begin{array}{c}\text { Stafford-Smith } \\
\text { and Carter }\end{array}$ & Mainstone & Žarnić & $\begin{array}{c}\text { Paulay and } \\
\text { Priestley }\end{array}$ & Eurocode 8 \\
\hline \multirow{4}{*}{ N2 } & $d_{y}(\%)$ & 0.035 & $0.04\{14\}^{1}$ & $0.08\{129\}$ & $0.06\{71\}$ & $0.04\{14\}$ & $0.05\{43\}$ \\
\cline { 2 - 7 } & $d_{u}(\%)$ & 0.561 & $0.6\{7\}$ & $0.73\{30\}$ & $0.67\{19\}$ & $0.65\{16\}$ & $0.62\{11\}$ \\
\cline { 2 - 7 } & $V_{y}(\mathrm{kN})$ & 75 & $67\{11\}$ & $50\{33\}$ & $106\{41\}$ & $73\{3\}$ & $63\{16\}$ \\
\cline { 2 - 7 } & $V_{u}(\mathrm{kN})$ & 195 & $194\{1\}$ & $160\{18\}$ & $240\{23\}$ & $226\{16\}$ & $183\{6\}$ \\
\hline \multirow{4}{*}{ C1 } & $d_{y}(\%)$ & 0.029 & $0.032\{10\}^{1}$ & $0.04\{38\}$ & $0,05\{72\}$ & $0.04\{38\}$ & $0.05\{72\}$ \\
\cline { 2 - 7 } & $d_{u}(\%)$ & 0.42 & $0.45\{7\}$ & $0.6\{43\}$ & $0.52\{24\}$ & $0.53\{26\}$ & $0.62\{48\}$ \\
\cline { 2 - 7 } & $V_{y}(\mathrm{kN})$ & 90 & $87\{3\}$ & $54\{40\}$ & $88\{2\}$ & $77\{14\}$ & $63\{30\}$ \\
\cline { 2 - 7 } & $V_{u}(\mathrm{kN})$ & 190 & $183\{4\}$ & $139\{27\}$ & $170\{11\}$ & $164\{14\}$ & $183\{4\}$ \\
\hline \multirow{4}{*}{ M2 } & $d_{y}(\%)$ & 0.042 & $0.047\{12\}^{1}$ & $0.05\{19\}$ & $0.05\{19\}$ & $0.09\{114\}$ & $0.05\{19\}$ \\
\cline { 2 - 7 } & $d_{u}(\%)$ & 0.53 & $0.49\{8\}$ & $0.75\{42\}$ & $0.5\{6\}$ & $0.49\{8\}$ & $0.58\{9\}$ \\
\cline { 2 - 7 } & $V_{y}(\mathrm{kN})$ & 240 & $202\{16\}$ & $75\{69\}$ & $190\{21\}$ & $183\{24\}$ & $121\{50\}$ \\
\cline { 2 - 7 } & $V_{u}(\mathrm{kN})$ & 324 & $319\{2\}$ & $163\{50\}$ & $304\{6\}$ & $255\{21\}$ & $211\{35\}$ \\
\hline
\end{tabular}

1 - Values in brackets \{\} are the relative errors, expressed as a percentage of the numerical value in relation to experimental one

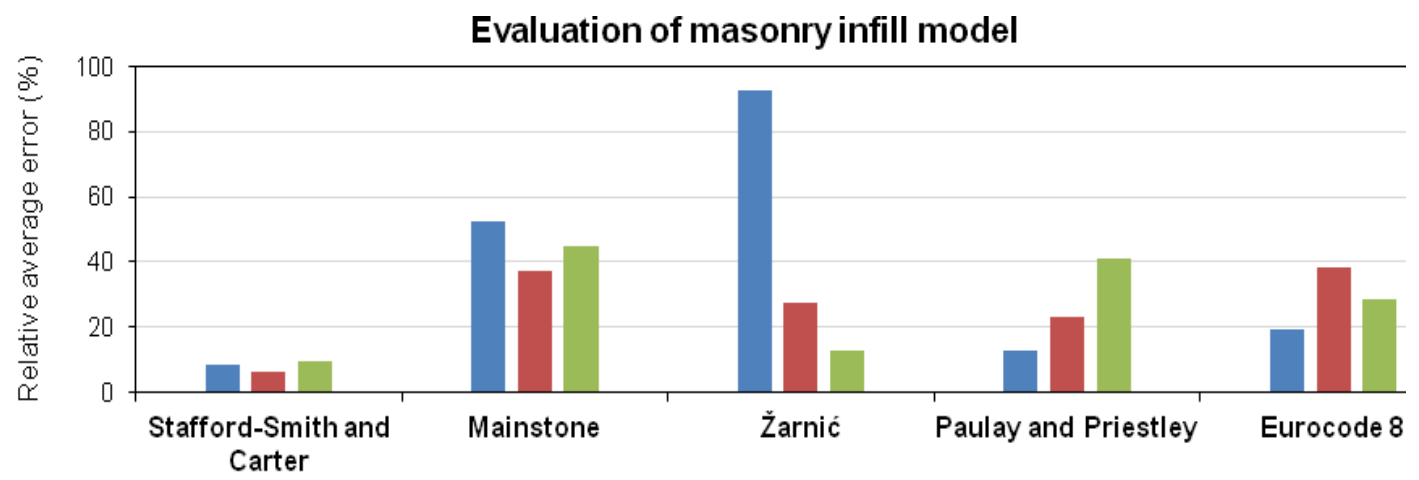

Recommedations of different authors for diagonal width $w$

aN2 model with weak infill $\quad$ aC1 model with medium infill $\quad$ 口M2 model with strong infill

Figure 7. Results of non-linear analysis

The quality of the representation of the local response of masonry infill was done by calculating the forcedisplacement tri-linear relation according to equations by Panagiotakos [26]. Force-displacement curves for the masonry infill were obtained from numerical non-linear models from Seismostruct [18]. A satisfactory correlation of numerically obtained with calculated curves was achieved, as illustrated by the obtained results shown of Fig. 8. 


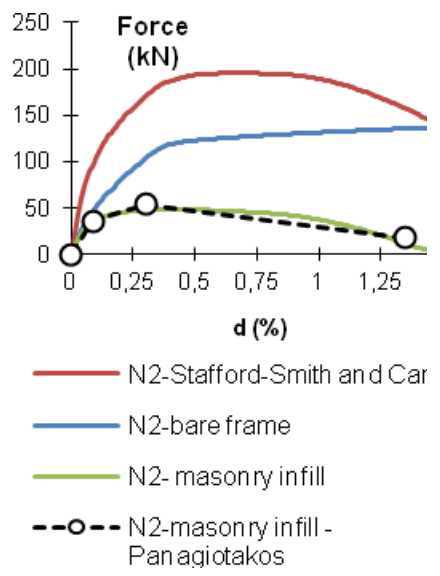

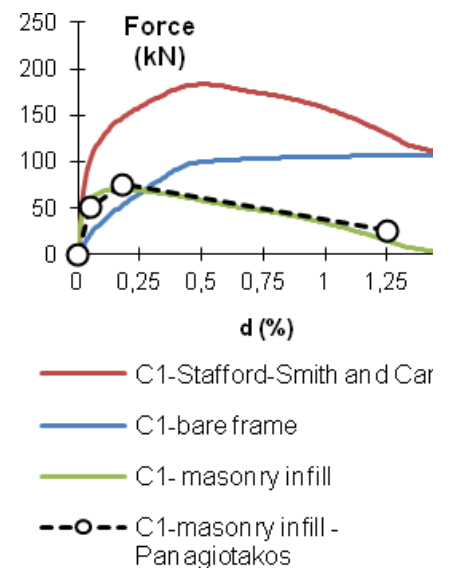

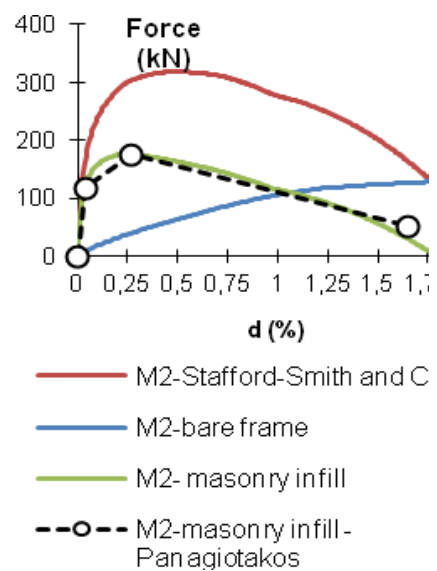

Figure 8. Local response of masonry infill, comparing numerical results and calculated curve, by Panagiotakos [26]

\section{Conclusions}

Reinforced-concrete frames with masonry infill- framed-masonry are often used and rarely modelled. We have investigated the main parameters required for proper modeling of infill panels embedded in RC frames that should give a useful guidance for the highlighted problems and better modelling knowledge of framed-masonry structures.

The critical review of significant references and the recommendations developed by the different authors show that the numerical response of infilled RC frames under horizontal loads is very sensitive to the specific parameters assumed in the numerical models. In particular, the selection of formulations for the width of the equivalent strut and the choice of the primary curves of the experimental samples of infilled frames are crucial aspects that have been specifically investigated in the presented research work.

The analyses have shown that the response of framed-masonry structures under lateral loading is not a mere sum of the responses of $\mathrm{RC}$ frames and masonry infill but rather its complex interaction. It can be modelled by use of the RC frame models and masonry infill model but with proper choice of the parameters. Mechanical properties of the masonry infill can be related to the value of the strut width masonry compressive strength (high value of compressive strength of masonry infill corresponds to high values of width). Proper choice of the infill's material parameters and combination with the changeable strut width enables proper representation of the systems behavior. By comparing a primary curves from three experimental samples with the results from nonlinear analyses performed with a panel model, the influence of the equivalent diagonal width on the overall structural response is clearly evident.

This numerical investigation indicated that Stafford-Smith and Carter's recommendations for the initial equivalent strut width can favorably predict the observed primary curve of the composite frame-masonry structure with different frame ratios and different infill typologies. It should be noted that recommendations for strut width made by other researchers (Mainstone, FEMA 356, Eurocode 8, and Paulay and Priestley) can be applied only within limitations according to the high sensitivity of the results related to the variation of masonry infill typology.

It is important to emphasize that numerical analysis were performed for one-story, one-bay infilled frame extracted from a building. This specific frame was fully and uniformly infilled, and the structural response was strongly influenced by the presence of the infill panels.

To make general suggestions for evaluating macro models that consider the effect of infill, further study of an entire building constructed from multi-story, multi-bay infilled frames structures is required. 


\section{Acknowledgment}

The research in this paper is part of the research project "Seismic design of infilled frames", No. 149-14929661536, supported by the Ministry of Science, Education and Sports of the Republic of Croatia, whose support is gratefully acknowledged.

\section{References}

[1] Fardis M.N.; Panagiotakos T.B.; Calvi G.M. 1998: Seismic response and design of masonry infilled reinforced concrete buildings, Structural Engineers World Congress, San Francisco, USA

[2] Mehrabi A.B.; Shing P.B.; Schuller M.P.; Noland J.L. 1994: Performance of masonry infilled R/C frames under in-plane lateral loads, Report CU/SR-94/6, University of Colorado, Boulder, USA

[3] Kappos A.J; Ellul, F. 2000: Seismic design and performance assessment of masonry infilled R/C frames, $12^{\text {th }}$ World Conference of Earthquake Engineering

[4] Smyrou E.; Blandon C.; Antoniou S.; Pinho R.; Crisafulli F. 2012: Implementation and verification of a masonry panel model for nonlinear dynamic analysis of infilled RC frames, Bulletin of Earthquake Engineering, Volume 9, Issue 5, pp. 1519-1534

[5] Asteris P.G.; Antoniou S.T.; Sophianopoulos D.S.; Chrysostomou C.Z. 2011: Mathematical macromodelling of infilled frames: state-of-the-art, Journal of Structural Engineering, Volume 137, Issue 12, pp. 1508-1517

[6] Hak S.; Morandi P.; Magenes G. 2013: Evaluation of infill strut properties based on in-plane cyclic tests, Građevinar, Volume 65, Issue 6, pp. 509-521

[7] Polyakov, S.V. 1956. Masonry in framed buildings (An investigation into the strength and stiffness of masonry infilling). Gosudarstvennoe izdatel'stvo Literatury postroitel'stvu i arkhitekture, Moscow [English translation by Cairns GL, Trans. National Lending Library for Science and Technology, Boston, Yorkshire, England, 1963].

[8] Holmes M. 1961: Steel frames with brickwork and concrete infilling, Proceedings of the Institution of Civil Engineers, Volume 19, pp. 473-478

[9] Stafford-Smith B. 1962: Lateral stiffness of infilled frames, Journal of Structural Division, Volume 88, Issue 6, pp 183-199

[10] Stafford-Smith B. and Carter C. 1969: A method for the analysis of infilled frames, Proceedings of the Institution of Civil Engineers, Volume 44, pp. 31-48

[11] Mainstone, R.J. 1971: On the stiffnesses and strengths of infilled frames, Proceeding of the Institution of Civil Engineers, Supplement IV, pp. 57-90

[12] Žarnić, R. 1992: Inelastic response of r/c frames with masonry infill, Ph.D. Thesis, University of Ljubljana, Slovenia

[13] FEMA 356, 2000: Prestandard and Commentary for the Seismic Rehabilitation of Buildings, American Society of Civil Engineers for the Federal Emergency Management Agency, Washington, D.C.

[14] CEN, Eurocode 8, 2004: Design provisions for earthquake resistance of structures. Part 1: Brussels

[15] Paulay, T.; Priestley, M.J.N. 1992: Seismic Design of Reinforced Concrete and Masonry Buildings, John Wiley \& Sons, New York, USA

[16] Crisafulli, F.J. 1997: Seismic behavior of reinforced concrete structures with masonyinfills, Ph.D. Thesis, Department of Civil Engineering, University of Canterbury

[17] Athol, J.C. 2008: RUAUMOKO-2D Inelastic Dynamic Analysis, University of Canterbury, New Zealand

[18] Seismosoft, 2013: "SeismoStructv6.5 - A computer program for static and dynamic nonlinear analysis of framed structures", available on http://www.seismosoft.com

[19] Decanini L.D.; Fantin, G.E. 1986: Modelosm simplificados de la mam postería incluida en pórticos. Características de rigidez y resistencia lateral en estadolímite" (in Spanish), Jornadas Argentinas de Ingeniería Estructural, Buenos Aires, Argentina, Volume 2, pp. 817-836

[20] Žarnić, R. 1985: The analysis of R/C frames with masonry infill under seismic actions, (in Slovene), FGG Ljubljana 
[21] Mander J.B.; Priestley M.J.N.; Park R. 1988: Theoretical stress-strain model for confined concrete,ASCE Journal of Structural Engineering, Volume 114,Issue 8, pp 1804-1826

[22] Menegotto M.; Pinto P.E. 1973: Method of Analysis for Cyclically Loaded Reinforced Concrete Plane Frames Including Changes in Geometry and Non-Elastic Behavior of Elements under Combined Normal Force and Bending, Symposium on the Resistance and Ultimate Deformability of Structures anted on by well defined loads, International Association for Bridges and Structural Engineering, Zurich, Switzerland, pp. 15-22

[23] Bertoldi S.H.; Decanini L.D.; Gavarini C. 1993: Telai tamponati soggetti ad azione sismica, un modello semplificato: confront sperimentale e numerico", (in Italian) atti del 6 convegno nazionale ANIDIS, Volume 2, pp. 815-824

[24] Kalman Šipoš T.; Sigmund V.; Hadzima-Nyarko M. 2013: Earthquake performance of infilled frames using neural networks and experimental database, Engineering Structures, Volume 51, pp. 113-127

[25] Colangelo F. 2005: Pseudo-dynamic seismic response of reinforced concrete frames infilled with nonstructural brick masonry, Earthquake Engineering and Structural Dynamics, Volume 34, pp. 1219-124

[26] Panagiotakos T.B.; Fardis M.N. 1996: Seismic response of infilled RC frames structures, $11^{\text {th }}$ World Conference on Earthquake Engineering, Acapulco, México, June 23-28. Paper No. 225. 